\title{
0 cinema de John Akomfrah e as latências de porvir da memória diaspórica
}

The cinema of John Akomfrah and the latencies of future in the diasporic memory

Rodrigo Sombra ${ }^{1}$

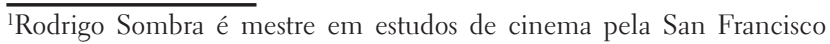
State University (2014) e doutorando do Programa de Comunicação e Cultura da Universidade Federal do Rio de Janeiro. Pesquisa financiada pela Capes. E-mail: rodrigosombrax@gmail.com 
Resumo: A partir da hipótese de que o cinema estaria apto a produzir uma escrita historiográfica própria, mediante seus recursos expressivos, este artigo investiga o lugar da diáspora africana na obra do realizador britânico John Akomfrah. À luz do cruzamento entre imagem e história formulado por Walter Benjamin, analiso os usos de imagens de arquivo que captam a experiência de membros das antigas colônias britânicas emigrados à Grã-Bretanha do pós-guerra no filme The Nine Muses (2010). Argumento que em Akomfrah os materiais de arquivo excedem a condição de registro circunscrito a dar testemunho do momento em que vieram a existir, revelando potências submersas na atualidade pós-colonial.

Palavras-chave: diáspora africana; cinema diaspórico; John Akomfrah; Walter Benjamin; arquivo.

Abstract: Departing from the hypothesis that the cinema could produce its own form of historiographical writing, this article explores the presence of the African diaspora in the work of the British filmmaker John Akomfrah. In the light of the link between image and history formulated by Walter Benjamin, I analyze the uses of archival footage that capture the experience of immigrants from the former British colonies in postwar Britain in the film The Nine Muses (2010). I argue that in Akomfrah's work the archival footage extrapolate its usual documentary status whose function is solely bear witness of the moment they came into existence, revealing new potencies in the post-colonial contemporaneity.

Keywords: African diaspora; diasporic cinema; John Akomfrah; Walter Benjamin; archive. 
"Não há histórias dos levantes, apenas fantasmas de outras histórias". Escutadas em Handsworth Songs (1986), documentário sobre os protestos que à época irrompiam nos bairros de imigrantes em Birmingham, estas palavras poderiam calhar como epígrafe para toda a obra de seu diretor, John Akomfrah. Ganês radicado na Inglaterra desde a infância, Akomfrah tem dedicado filmes, vídeos e instalações a problematizar os usos e desvantagens da história para o sujeito diaspórico. Em suas criações, um fato nunca se dá a ler em suas contingências. Um período sempre convoca a memória de outro; uma imagem sempre conjura fantasmas de outras histórias. Transcorridas três décadas desde o lançamento de Handsworth Songs, seu primeiro filme, Akomfrah ocupa hoje um lugar paradigmático na cinematografia britânica. Fundador do coletivo Black Audio Film Collective, ele é um dos principais expoentes do novo cinema negro surgido na Grã-Bretanha nos anos 1980. Composto por imigrantes e filhos de imigrantes, o Black Audio ampliaria o repertório de possibilidades expressivas da arte britânica ao fazer da experiência diaspórica um foco de radicalidade a um só tempo estética e política.

Segundo Kobena Mercer, o coletivo dispunha de procedimentos do cinema experimental a fim de "escavar uma contra-memória creole da luta negra no Reino Unido, ela mesma sempre reprimida, apagada e tornada invisível na "memória popular' do cinema e da mídia dominantes" (MERCER, 1994, p. 58, tradução nossa). No caso de Akomfrah, o ímpeto por tecer histórias alternativas ganha forma de um cinema de apropriação. Sua obra é conhecida pelo uso de materiais alheios, por organizar combinações de rastros (imagens, sons, palavras) sacados de fontes e períodos distintos, ativando súbitas montagens de passado e presente. É o caso de Handsworth Songs, em que o cenário de racismo, terror policial e sublevações populares da era Thatcher, captado a quente pela câmera do diretor, reencontra a utopia de imigrantes desembarcados na Inglaterra do pós-guerra inscrita em imagens de arquivo.

Ao ocupar galerias, festivais de cinema e televisão, Akomfrah contribuiu para consolidar a questão diaspórica no centro do debate cultural britânico. Vista em conjunto, sua obra conforma uma espécie de cartografia da diáspora africana traçada a partir da imagem. As rotas nela esboçadas cobrem um arco temporal amplo, perpassam as ruínas do projeto socialista ganês, revisitadas em Testament (1988), a vida de intelectuais como Stuart Hall e Malcolm X, ou o mar como espaço de catástrofe contínuo na alternância de imagens da pesca industrial e evocações do tráfico negreiro da videoinstalação Vertigo Sea (2015). O que está na raiz de todos esses trabalhos é o impulso de dispor do passado para incidir sobre o agora. Akomfrah se notabilizou por revisitar obstinadamente o arquivo audiovisual do século XX, processo pelo qual 
se nutre da história não para restaurar aquilo que foi, mas para afilar o olhar sobre seu próprio tempo. Segundo o diretor, essas práticas serviriam para traçar uma "contra-cartografia [...] um mapa no qual se renavega o presente" (AKOMFRAH, 2015b, p. 35, tradução nossa).

Este artigo se interessa em investigar os modos pelos quais Akomfrah visita o contemporâneo a partir da história. Propõe-se a pensar como a imagem do arquivo pós-colonial, uma vez arrancada de seu contexto de origem e reinscrita em novos circuitos, abre-se a potências imprevistas no momento de sua feitura, cobrando sua atualidade no presente. Sustento a hipótese de que ao fazer seus filmes, Akomfrah atuaria também como um historiador. Ou antes um historiador das imagens empenhado em reanimar memórias da diáspora africana, mediante operações de montagem, entendidas aqui na formulação de Walter Benjamin, a um só tempo princípio estético e forma de conhecimento. Investigo essa proposição a partir da análise do documentário The Nine Muses (2010), filme dedicado à experiência da imigração na Grã-Bretanha do pós-guerra. Aproximo-me, portanto, de reflexões dedicadas a pensar como o cinema - em especial aquele voltado ao arquivo - poderia ser percebido não como mera fonte material ou suporte iconográfico, mas veículo operatório na concepção de modelos visuais aptos a interpelar a história.

O uso ostensivo de imagens de arquivo na obra de Akomfrah e suas relações com a história excedem o domínio da representação. À diferença do documentário clássico, afeito aos materiais de arquivo por sua função ilustrativa de um passado que se supunha imaginável por meio do cinema, na obra do realizador britânico eles se apresentam como objeto mesmo de problematização. Em Akomfrah, a imagem de arquivo configura-se como dado elusivo ao qual o olhar é instado a sondar, investigar, analisar. Será por meio das recombinações outorgadas pela montagem, da ativação de relações antes insuspeitadas entre uma e outra imagem, ou entre imagem e palavra postas em contato, que o arquivo evocará a experiência de comunidades diaspóricas cujas memórias, muitas vezes, jamais chegariam a se materializar em suportes como o filme ou a fotografia. Seguir os meandros da história em Akomfrah requer atinar para a emergência do arquivo como problema também para a historiografia do século XX. O esforço de Foucault em A arqueologia do saber (2007) é medular nesse sentido. Contra a noção corriqueira de arquivo, que nos remete a gabinetes empoeirados apinhados de gavetas, Foucault concebe-o como formação discursiva, regime regulador das condições de possibilidade dos enunciados de uma época ou campo do saber. "O arquivo é, de início, a lei do que pode ser dito, o sistema que rege o aparecimento dos enunciados como acontecimentos singulares” (FOUCAULT, 2007, p. 149). 
Sob essa forma, o arquivo designa não apenas uma materialidade - ele é feito também de uma série de taxonomias, classificações, figuras do conhecimento e da cultura que definiriam o a priori histórico a partir do qual os enunciados ganham corpo. Essa concepção ampliada de arquivo está atrelada à crítica do documento elaborada por Foucault. Com A arqueologia do saber (2007), tentava teorizar o desenvolvimento de uma história não mais interessada em investigar os documentos a fim de recobrar uma época como se esta estivesse passivamente à espera de reconstituição. Para essa nova história, o documento estaria investido de uma potência relacional. Importava menos interpretá-lo, verificar seu teor de verdade e seu conteúdo expressivo, do que situá-lo em relação a outros documentos, fundar novas séries discursivas, reordená-las de modo a descobrir novas descontinuidades. Isto é, de instrumento inerte o documento passa à condição de objeto a ser elaborado pelo historiador, aquilo que caberia montar a fim de constituir o conhecimento histórico.

Essa reavaliação do arquivo no campo teórico é coextensiva ao desenvolvimento de uma série de práticas artísticas do século XX. Na obra de autores como Resnais, Farocki, Godard, para ficar em nomes paradigmáticos no campo do cinema, a imagem de arquivo já não poderia mais ser pensada como matéria neutra, mero rastro que nos devolveria placidamente ao que foi. O olhar sobre o arquivo seria também reconfigurado por relações dinâmicas das sociedades com o passado, mudanças tecnológicas e disputas pelo acesso público a acervos visuais. Nas palavras de Sánchez-Biosca (2005, p. 221), o arquivo audiovisual deve ser entendido como "um sistema complexo em contínuo processo de ativação e mudança”. Dessa forma, não podemos jamais percebê-lo como "um material bruto, uma estática disposição de fontes; ele é, a depender do caso, uma norma, uma promessa, uma ameaça de discurso" (SÁNCHEZ-BIOSCA, 2005, p. 221, tradução nossa).

A fim de matizar a reflexão sobre história, imagem e diáspora aqui esboçada, recorro em particular à obra de Walter Benjamin. Pensar Akomfrah a partir de Benjamin me parece pertinente não apenas por tudo aquilo que suscita a afinidade eletiva reivindicada pelo realizador ${ }^{2}$, mas sobretudo pelo modo fecundo como a questão da imagem atravessa a obra do pensador alemão. Nesse percurso, Benjamin não só deslocou a imagem à condição de objeto primordial da investigação histórica, mas intuiu o próprio trabalho historiográfico como imagem. É notório o impacto do cinema soviético de montagem em seu pensamento. A fotografia tam-

\footnotetext{
${ }^{2}$ Benjamin é reconhecidamente uma referência para Akomfrah. Para ficar no exemplo mais patente dessa aproximação, o título de um dos filmes do cineasta britânico, The Last Angel of History (1996), faz menção à célebre alegoria do Angelus Novus, de Paul Klee, citada pelo crítico alemão em Sobre o conceito de história (1940).
} 
bém assumiria um papel de relevo e o ensaísta chegaria a descrever seu historiador materialista como fotógrafo ou como revelador fotoquímico apto a tornar manifesto o "índice secreto" oculto nas imagens do passado (BENJAMIN apud CADAVA, 1997). Ao perceber como a reprodutibilidade técnica e os novos ritmos tecnológi$\cos$ da modernidade reconfiguravam as estruturas da experiência subjetiva, Benjamin intuía também a emergência de novas estruturas do conhecimento. A aparição da fotografia e do cinema postulava assim uma virada epistemológica, convocava a pensar não só os novos rumos da arte e da política, mas a "formação dos conceitos em geral", inclusive aqueles a serviço do historiador (CADAVA, 1997). Creio ainda que a própria temporalidade suscitada pelo modelo historiográfico benjaminiano e sua ênfase na memória dos mortos sejam também rentáveis para dimensionar o lugar da história no cinema de Akomfrah.

\section{The Nine Muses: diáspora e história imagética}

The Nine Muses talvez constitua a principal tentativa de Akomfrah de conceber uma escrita cinematográfica da história. Documentário montado a partir de imagens de arquivo da BBC, é sua elegia aos imigrantes que desembarcaram na Grã-Bretanha à procura de uma vida mais tolerável no pós-guerra. Esforço de captar as aspirações e vicissitudes daquela que viria ser conhecida por "geração Windrush", em referência ao navio homônimo que em 1948 aportou na Inglaterra repleto de tripulantes caribenhos; cena inaugural das ondas migratórias que viriam a definir a atual composição multiétnica do Reino Unido. Nesse filme, ele se propõe a investigar “como alguém ‘devém’ imigrante. Como você se move de um lugar de certeza - seu país, sua cidade, seu continente - para esse outro, que, na verdade, não é nem aqui nem lá" (AKOMFRAH, 2011, p. 62, tradução nossa). Buscar os rastros dessa experiência a partir de registros documentais é confrontar-se com as lacunas do inventário audiovisual britânico. Se imagens de arquivo são índices que conformam certa ideia de herança cultural, fragmentos que restam do passado e que nos unem a ele no presente, a experiência da diáspora africana no pós-guerra - marcada pelo trânsito, pela separação não raro traumática da terra natal, e por uma recepção muitas vezes hostil no lugar de destino - é definida pela escassez desse tipo de objeto. A maior parte das fontes às quais Akomfrah recorre em The Nine Muses foi filmada por cinegrafistas a serviço de cinejornais, reportagens e documentários rodados sobre as comunidades imigrantes entre os anos 1948 e 1970. De acordo com o autor, pouco ali consegue exprimir a vivência íntima daqueles enquadrados pela câmera: 
Os imigrantes eram muitas vezes filmados em relação a debates sobre o crime ou problemas sociais, então é assim que eles ficaram fixados na memória oficial. Mas aquela mulher caribenha de pé numa fábrica em 1960 não está pensando em como ela é uma imigrante ou se é um fardo para o Estado britânico; é mais provável que ela esteja pensando sobre o seu amante ou sobre o que ela vai comer naquela noite. (AKOMFRAH, 2012, s/p, tradução nossa)

Akomfrah não se compraz no lamento pelas imagens que jamais vieram a ser e decide abraçar aquelas existentes, mesmo naquilo que são incapazes de expres$\operatorname{sar}^{3}$. Diante dos registros que dão testemunho de como a cultura hegemônica britânica percebia os imigrantes, reconhece as ausências, os silenciamentos, as violências da história, bem como se vê assaltado por vestígios que clamam por serem visados no presente. "Dizem que as vidas diaspóricas são caracterizadas pela ausência de monumentos [...], mas, de certa forma, o inventário arquivístico é esse monumento" (AKOMFRAH, 2011, p. 62, tradução nossa). Assim, por identificar um uso nos filmes do arquivo, reconhece uma qualidade irredutível no registro cinematográfico, assume que aquelas imagens não serviriam apenas como ancoragem visual das redes discursivas que a produziram e nas quais vieram a circular. Mais que documento, "toda imagem é uma súplica por um futuro”, afirmou certa vez o realizador (AKOMFRAH, 2015a). Em Akomfrah, a lida com o arquivo é indissociável da busca por essas latências de porvir, do ímpeto por ativar aquilo que na superfície das imagens se desgarra do tempo de sua origem e nos interpela no presente.

Essa concepção da imagem como objeto pleno de devires remete à visão da história apregoada por Benjamin. Afinal, também o ensaísta alemão vê o passado como problema incompleto, como campo prenhe de potencialidades irrealizadas. Aos olhos do historiador que Benjamin tem em mente, “a obra do passado não é acabada. Ele não pode considerar nenhuma obra, em nenhuma parte, como cabendo para uma época enquanto disponível sem mais" (BENJAMIN; TARNOWSKI, 1975, p. 43, tradução nossa). Portanto, não seria possível restringir o sentido de um documento histórico ao momento que lhe foi dado a existir. Diante de uma fotografia, por exemplo, nos confrontamos com a atualidade inscrita na imagem, mas também com o que escapa à intenção do fotógrafo, aquilo que extrapola a percepção de seus contemporâneos, o impensado. Na perspectiva benjaminiana, toda imagem deve ser lida

\footnotetext{
${ }^{3}$ Não tive acesso aos filmes reempregados por Akomfrah em The Nine Muses. No entanto, artigos voltados ao filme, como os trabalhos assinados por Kass Branning, Stéphane Symons e Matthias De Goof, todos incluídos no dossiê dedicado ao diretor pela revista Black Camera (2015), ou a tese de doutorado de Maria Jose Peschard (2014), chancelam a visão do realizador a respeito da natureza dos materiais de arquivo aos quais recorreu.
} 
como processo, uma bifurcação sempre a oscilar entre um valor documental e uma potência de transfiguração.

Em suas conferências sobre o conceito de arquivo, nas quais Benjamin é citado, Jacques Derrida expõe ideia semelhante sobre a temporalidade dos artefatos históricos. Para o filósofo francês, o arquivo não está voltado ao passado, mas pressupõe fundamentalmente o futuro. Derrida lembra que o vocábulo "arquivo" remete à palavra grega "arkhé", dotada de um duplo significado: "começo" e "comando". A estes, acrescente-se o sentido de "domicílio", oriundo de "arkhê̂on", termo que designava a casa dos arcontes, os magistrados gregos, guardiões do arquivo e cidadãos investidos do poder da lei. Arkhé, arkheîon e arconte: o arquivo seria, portanto, uma origem, um lugar e uma prerrogativa de exercício da lei. Derrida ressalta que o poder delegado aos arcontes incluía o ofício de registrar, conservar e ordenar os documentos do arquivo, mas também de interpretá-los. Dado esse caráter exegético, aquilo que o arquivo pode conter não está totalmente circunscrito aos traços patentes na documentação, pois está aí implicada a posterioridade de toda operação de leitura. Sobre a memória de um acontecimento inscrita num suporte material - em suma, o documento - paira um registro virtual a ser escavado pelo intérprete do futuro, consagrando o sentido do arquivo a um perpétuo vir-a-ser. Estaria na raiz mesma do arquivo esse jogo de sempre diferir e seria própria do arquivista a tarefa de ler nos textos as lacunas, aquilo que os textos recalcam, suprimem, rasuram. Derrida (2001, p. 51) argumenta que o reconhecimento dessa virtualidade jaz numa radical indeterminação: “o arquivo, se queremos saber o que isto teria querido dizer, nós só o saberemos num tempo por vir. Talvez. Não amanhã, mas num tempo por vir, daqui a pouco ou talvez nunca”. Benjamin interpretava esse perpétuo vir-a-ser dos objetos históricos à luz dos dispositivos da modernidade industrial, como em sua alegoria do historiador como revelador fotoquímico: "Só o futuro dispõe de reveladores suficientemente potentes para que a imagem captada se torne visível com todos os seus detalhes" (BENJAMIN apud CADAVA, 1997, p. 87, tradução nossa). De modo mais incisivo, essa dimensão de futuridade estaria no cerne de sua formulação da imagem técnica, havendo na reprodução fotográfica do mundo sempre um resto, um excesso cuja existência assume o caráter de uma espera. Para Benjamin, o historiador deve atentar à fotografia, pois nela o real invariavelmente chamusca a imagem com "uma pequena centelha do acaso [...] lugar imperceptível em que o futuro se aninha ainda hoje no ‘ter sido assim’ desses minutos únicos, há muito extintos, e com tanta eloquência que, olhando para trás, podemos descobri-lo" (2012, p. 100). 
O reconhecimento dessa "pequena centelha do acaso" seria determinante para as apropriações do arquivo em Akomfrah. Isso é patente na atenção dedicada ao detalhe aparentemente marginal inscrito nos materiais utilizados em The Nine Muses. A fim de acentuar as múltiplas latitudes da imagem, um dos procedimentos recorrentes no filme é o uso da câmera lenta. A desaceleração é aplicada, por exemplo, a planos filmados no interior de fábricas, quando assistimos a uma sucessão de operárias em ação. Uma vez inseridos em outra temporalidade, o que importa já não é mais o registro do dia a dia na fábrica, mas o detalhe periférico: o olhar das mulheres, cada um deles alheio à câmera que os captura em enquadramentos cerrados. Refreada a velocidade do tempo e tornada a ação rarefeita, Akomfrah engaja o espectador em novos modos de ver. Passa-se, portanto, da visão do gesto ordinário da mulher entre máquinas à sugestão de uma pergunta sobre a sua vida interior. Isso nos é suscitado, em parte, pelo modo como a montagem situa a direção dos olhares. Akomfrah joga com a convenção do campo/contracampo ao intercalar a série de close-ups das operárias em perfil com a imagem de outra mulher negra na praia, voltada na direção oposta, a ensaiar repetidas saudações ao mar. Recorre a esse procedimento não para reafirmá-lo convencionalmente ou para exibir seu artificialismo. Antes, o corte realça a descontinuidade intrínseca à montagem em outro nível, abre-se a uma interrogação sobre o anseio diaspórico de retornar ao lugar de origem evocado pelo uso intempestivo do Zaratustra de Nietzsche que acompanha as imagens em voz over: "Ó, soledade! Pátria minha! Vivi muito tempo selvagem em selvagens países estranhos para não regressar a ti sem lágrimas!” (2008, p. 342).

The Nine Muses está dividido em nove capítulos, cada um deles dedicado a uma das musas filhas de Zeus e Mnemosyne, a deusa grega da memória. Se é possível atribuir ao filme uma ossatura narrativa, esta seria inspirada sobretudo na Odisseia, texto que, ao lado de obras de Nietzsche, Joyce, Emily Dickinson, T. S. Eliot, Milton, Beckett, Shakespeare, empresta as citações a que Akomfrah recorre em voz over para ativar as latências contidas nas imagens de arquivo. Todavia, o jogo narrativo não descreve com precisão a montagem composta pelo realizador. À exceção dos entretítulos que anunciam cada novo capítulo, The Nine Muses transcorre livre de qualquer moldura explicativa. Não há menção à data dos acontecimentos registrados nas imagens, nem são identificados o título ou o diretor dos filmes dos quais cada uma delas provém; tampouco são creditadas as referências literárias ou nomeados os três entrevistados cujo depoimento escutamos em cena. Emblema das migrações em questão, a palavra "Windrush" está de todo ausente. Assim, ao encadeamento narrativo sobressaem a pulsação, os valores plásticos e rítmicos, as consistências e 
variações da montagem. Mais que narrar, Akomfrah convoca o espectador a seguir motivos visuais e literários justapostos sucessivamente, alternando múltiplas chaves de leitura sobre o fenômeno da diáspora africana no Reino Unido.

Um dos motivos mais persistentes é o confronto entre figura humana e paisagem. Intercaladas aos materiais de arquivo, vemos ressurgir seguidas vezes a imagem de um sujeito encapuzado contra uma paisagem enevoada. O contraste entre figura e fundo é realçado pelo amarelo berrante do casaco e o cenário monocromático da cadeia de montanhas ao longe. Diante dessa figura solitária rodeada pela neve, a presença insistente do mar. Filmadas por Akomfrah no Alaska, essas imagens são descritas pelo diretor como uma alegoria à experiência diaspórica, ao embate do imigrante com o frio do clima temperado e à aparição do colorido de seus trajes nativos na cinza Grã-Bretanha, cujo racionamento de tintura no pós-guerra furtava aos locais o privilégio da cor (AKOMFRAH, 2015b). Essa visão de uma paisagem hostil reverbera ainda nas imagens de arquivo de nevascas, enchentes, incêndios; também em espaços urbanos, nos edifícios arruinados, acidentes automobilísticos, nas inscrições racistas que recobrem os muros ("Você já arrastou uma corrente?"; "Mantenha o Reino Unido branco"). A animosidade reiterada nessas figuras do espaço nos endereça às tensões que se seguiriam ao desembarque do Windrush ao final dos anos 1940.

Entre muitos imigrantes, a mudança de país se revelaria problemática pela própria natureza de suas expectativas. Grande parte dos homens e mulheres recrutados para suprir a escassez de mão de obra no Reino Unido do pós-guerra fora educada ainda no sistema colonial. Embora antilhanos, foram ensinados a reverenciar a Grã-Bretanha como sua pátria. Deakin et al. (1970, p. 283, tradução nossa) relatam que os membros da geração Windrush "levavam a sua britanidade a sério, e muitos deles não se consideravam forasteiros, mas tipos ingleses. Tudo aquilo ensinado na escola encorajava essa crença”. Decerto, o encontro com a realidade não poderia resultar mais contraditório. Em geral, os britânicos eram indiferentes ao vínculo histórico que os unia aos habitantes das antigas colônias e, embora leis segregacionistas não vigorassem na região, medidas discriminatórias eram corriqueiras. Peter Fryer (1988) descreve o pós-guerra no Reino Unido como um "período laissez-faire” em relação às práticas racistas. À época, não só os postos de trabalho oferecidos aos imigrantes eram os mais baixos, como seus salários eram menores quando comparados aos de colegas brancos empregados na mesma função. Em diversas cidades inglesas, sindicatos chegariam a instituir um limite de profissionais negros a serem admitidos e a cisão racial manifestada na organização do trabalho se estendia a diversos outros aspectos da vida social. Em meados da década de 1950, um terço dos cidadãos britânicos bran- 
cos objetava o casamento inter-racial e julgava por bem jamais convidar um negro para suas casas (RICHMOND, 1961, p. 240-206). O racismo ganhava forma sob um vasto espectro de ações, desde insultos verbais a linchamentos. De acordo com Fryer (1988, p. 379, tradução nossa), "estimulados pela propaganda fascista que clamava pela expulsão dos negros da Grã-Bretanha, ataques racistas eram lugar-comum no cotidiano dos negros que viviam em Londres por volta de 1958". Naquele mesmo ano, milhares de ingleses tomariam as ruas unidos em marchas pró-deportação.

Com efeito, a chegada de antilhanos, africanos e nativos do subcontinente asiático encetaria uma crise na autoimagem dos britânicos como população homogênea e etnicamente unificada. Como consequência, uma série de medidas legais adotadas à época terminaria por restringir a chegada de novos imigrantes e por rebaixar a cidadania daqueles já estabelecidos no país. A partir da década de 1960, nativos da Commonwealth emigrados à Grã-Bretanha poderiam ser deportados sob a vaga alegação de "interesse público". Conjugado a isso, crescia a incidência de abusos policiais cometidos contra imigrantes e o discurso racista não tardaria a ser convertido em plataforma política. "Se você quer um vizinho preto, vote no Partido Trabalhista”, dizia o slogan de campanha do candidato conservador nas eleições de Smecwick, em 1964. Quatro anos depois, o senador Enoch Powell, artífice das campanhas pró-deportação, daria em Birmingham o histórico discurso "Rivers of Blood". Citada em The Nine Muses, a fala de Powell é carregada de imagens xenófobas - trabalhadores estrangeiros incompetentes, escolas e maternidades tornadas inacessíveis por transbordarem filhos de imigrantes - que ajudariam a galvanizar a presença do outro étnico como signo de um desastre iminente. Por outro lado, a resistência das comunidades de imigrantes ganharia múltiplas frentes. Greves, organizações de bairro e aparição de uma imprensa alternativa negra multiplicaria os fronts de autodefesa e gerariam laços de solidariedade com militantes e sindicatos locais (ver FRYER, 1988). Nesse contexto, células políticas vinculadas ao ideário Black Power, como a comunidade liderada por Michael de Freitas em Londres e cuja história é revisitada por Akomfrah no filme Who Needs a Heart? (1991), logo se fixariam no imaginário contracultural britânico.

Paul Gilroy argumenta que a inadequação experimentada pela geração Windrush persiste neste século. Alega que netos de imigrantes do pós-guerra nascidos e criados no Reino Unido continuariam a não ser reconhecidos “como substantivamente britânicos" (GILROY, 2005, p. 128, tradução nossa). Em vez disso, aos olhos do establishment político e midiático, são vistos como se tivessem acabado de chegar, descartados como se nunca tivessem feito parte da nação e partilhado a sua história. 
"Desprovido de historicidade [...] o imigrante parece estar sempre estagnado no presente" (GILROY, 2005, p. 135, tradução nossa).

The Nine Muses incide sobre essa "ausência de historicidade" a fim de contestá-la, mas não para dar visibilidade aos saberes subalternos a partir do testemunho inscrito nos filmes de arquivo. Akomfrah não recua à imigração do pós-guerra para restaurar uma voz, senão para construí-la. Em The Nine Muses, as imagens de arquivo flutuam de par com palavras não creditadas que exprimem vicariamente as derivas da experiência diaspórica. Será Joyce ou T. S. Eliot quem verbalizará aquilo que as imagens do passado são incapazes de dizer. Essa montagem no qual aquilo que se ouve dificilmente coincide com o que se vê parece calhar ao entendimento da diáspora africana nutrido pelo realizador. Em diversos ensaios e entrevistas, ele ressalta como o fardo psicológico do exílio tende a resistir a formas discursivas estáveis. Exprime o embate por tornar legíveis os padecimentos do imigrante na Grã-Bretanha do pós-guerra. O esforço empreendido pelo sujeito em narrar suas vivências, em elaborar a situação de precariedade econômica, social, cultural, o estranhamento diante de si e do mundo novo que veio a habitar. Essa fissura aberta entre experiência e discurso é suscitada pelas recorrentes citações a Beckett em The Nine Muses. A presença de motivos beckettianos enfatiza a insuficiência da palavra e revela o "devir imigrante" mencionado por Akomfrah como dor pungente e refratária à linguagem. Às imagens de arquivo de imigrantes trabalhando numa lavanderia ou na cozinha, o cineasta justapõe trechos da abertura de O inominável (BECKETT, 1989, p. 29):

Quem agora? Sem me perguntar. Dizer eu. Sem pensar. Chamar isso de perguntas, hipóteses. [...] que devo fazer, na situação em que estou, como proceder? Por aporia pura ou melhor por afirmações e negações invalidadas à medida que são expressas [...] Deve haver outros expedientes. Senão seria um desespero total. Mas é um desespero total [...] O fato parece ser, se na situação em que me encontro pode-se falar de fatos, não apenas que eu vá ter de falar de coisas das quais não posso falar, mas ainda, o que é ainda mais interessante, que eu, o que é ainda mais interessante, que eu, não sei mais, não faz mal. Entretanto sou obrigado a falar. Não me calarei nunca. Nunca.

Insinua-se assim aquilo que não se pode traduzir, a vivência intransitiva que exige ser contada. Além disso, não haveria no agenciamento desse sujeito beckettiano que balbucia diante da experiência traumática, do "desespero total", uma correlação possível - suscitada pela superposição da palavra sobre os corpos negros que o olho da câmera parecia querer buscar sempre nas fábricas ou na cozinha - com aquilo que Du Bois um dia descreveu no contexto diaspórico afro-americano como "dupla 
consciência”? Isto é, a subjetividade cindida do exilado numa terra que não é sua, a "sensação de sempre olhar para o seu eu através dos olhos dos outros, de medir a sua alma com a trena de um mundo que o observa com divertido desprezo e piedade" (DU BOIS, 1999, p. 39). Há ainda na alusão a Beckett uma confissão de outra ordem. O paradoxo sugerido pelo imperativo de narrar diante da ausência de palavras, ou da falta de um "eu” suficientemente estável à enunciação, remete à própria figura do autor. Ao apossar-se de O inominável, Akomfrah também se pergunta como poderia ser possível narrar a partir das imagens de arquivo, através "dos olhos dos outros", as memórias da geração Windrush. Afinal, que lugar deve ocupar o realizador às voltas com o arquivo? O diretor britânico parece responder com modéstia, como se mobilizado pelo ímpeto de desaparecer, de submergir nos materiais apropriados. Se naturalmente é ele quem escolhe e organiza os fragmentos de seus filmes, em The Nine Muses, obra em que abundam palavras, não há uma linha sequer de sua autoria. Tampouco se ouvirá sua voz. The Nine Muses aspira assim a uma tarefa historiográfica à maneira da "arte de citar sem aspas" exortada por Benjamin. Aquilo que ele viria a definir, a partir da montagem, como seu método de trabalho: "Não tenho nada a dizer. Somente a mostrar" (BENJAMIN, 2006, p. 502).

\section{Arquivo e latências de porvir}

Pensar os meios pelos quais The Nine Muses enuncia uma escrita historiográfica nos convoca a atinar para o campo de reflexão mais amplo que investiga em quais condições o cinema produziria uma forma de pensamento. Nesse terreno, é central o estudo das relações entre imagem e palavra. A suposição do filme como forma teórica é frequentemente associada às possibilidades facultadas pelo discurso verbal. Um dos modos possíveis de situar a emergência de tais procedimentos argumentativos na história do cinema é pensar o momento em que o narrador do documentário se emancipa de sua tradicional função expositiva, entrando em crise a autoridade da "voz de deus" clássica. Essa ruptura situa a passagem do discurso impessoal que antes presidia o filme não ficcional a outro de veia ensaística. Doravante, a voz no documentário permitiria também encarnar uma subjetividade que tateia o mundo, que reflete, especula, hesita ante aquilo que a imagem dá a perceber. André Bazin tomaria nota dessa virada ao flertar com a hipótese de um filme em forma de ensaio em sua crítica de Cartas da Sibéria (1957), de Chris Marker. Neste artigo publicado em 1958, propõe a noção de montagem horizontal, aquela cujo sentido se dá preferencialmente "do ouvido ao olho", isto é, na qual "uma imagem não se 
refere àquela que a precede, ou à que vem em seguida, mas, em vez disso, refere-se, digamos, lateralmente, ao que é dito." (BAZIN, 2003, p. 44, tradução nossa). Essa concepção baziniana de montagem se distingue por hierarquizar a relação entre verbal e visual. Tal predomínio da palavra não se limitaria à obra de Marker. Nas décadas seguintes ela viria a definir certa tendência de um cinema que, amparado pelo comentário verbal, se apropria de materiais alheios a fim de avançar uma análise da imagem pela imagem. O trabalho de Harun Farocki é paradigmático nesse sentido. Em ambos os casos, ao se assistir aos filmes de Marker e Farocki, tem-se a impressão de que é preciso desnaturalizar a função originária da imagem apropriada e voltar a olhá-la sob certa distância, em última análise enfraquecê-la, para que, através da mediação da palavra, sobressaia sua potência de pensamento.

O cinema de Akomfrah se aproxima dessa linhagem argumentativa. Há todavia distâncias notáveis. À diferença da radiografia farockiana ou da pedagogia de Marker, o uso da voz em The Nine Muses não sublinha as imagens com comentários do tipo analítico. Em Akomfrah, a palavra não é custódia da imagem. Sua montagem não hierarquiza uma banda sobre a outra. Há em The Nine Muses mais contágio entre imagem e texto, o tipo de entrelaçamento no qual o verbal e o visual se redefinem reciprocamente numa dialética contínua, sem síntese previsível, do que análise propriamente. Dessa maneira, se o realizador cita $O$ paraíso perdido sem identificá-lo não é para reafirmar no clássico seu valor universal, mas para deslocá-lo. Também Milton torna-se outro junto àquele imigrante que vemos desembarcar no porto de alguma cidade britânica do pós-guerra. O gesto de montagem no interior do quadro, justaposição de imagem e palavra, ecoa a lógica na qual a citação deve desautorizar o autor, desfazer suas certezas e também aquelas de quem a lê. Cita-se assim para desfazer o contexto. Cita-se para deflagrar um contágio.

O recurso a fontes literárias do cânone ocidental nos leva a pensar quais relações aqueles imigrantes podem ter estabelecido com os textos a eles associados em The Nine Muses. Seria legítimo usá-los para falar de suas vidas? O escritor americano James Baldwin, a quem Akomfrah dedica o filme Testament (1988), toca nessa questão em sua crítica à suposta cumplicidade dos artefatos culturais com o histórico de opressão racial no Ocidente. Baldwin era cético quanto aos modos pelos quais o sujeito diaspórico negro poderia herdar a tradição ocidental. Ou ao menos duvidava que fazê-lo não seria moralmente ultrajante. Para ele, "não haveria motivo para curvar-se a Shakespeare ou a Descartes, ou às catedrais de Westminster Abbey ou Chartres. Uma vez que esses monumentos se infiltram em sua atenção [a do negro], não se tem qualquer acesso honroso a eles" (BALDWIN, 1998, p. 381, tradução nossa). 
Inversamente, Akomfrah sustenta um vínculo irremediável. Filho de mãe emigrada na Inglaterra, o realizador foi educado em um sistema de ensino no qual Milton e Shakespeare eram curriculares. Para ele, os autores lidos na escola são parte de sua “iniciação à britanidade" e a familiaridade com esses textos "era comum entre várias crianças britânicas negras da minha geração [...] Não sinto como se essas fossem fontes menos legítimas para falar do que era essencialmente uma experiência britânica negra" (AKOMFRAH, 2012, s/p, tradução nossa). Assim, ao restituir os textos canônicos à geração Windrush, Akomfrah encena a própria demanda por inclusão do negro na cultura britânica. Kass Banning (2015, p. 142, tradução nossa) identifica nesse enlace de citações literárias e imagens de arquivo as "tensões produtivas da experiência de peregrinação do imigrante pelos textos ocidentais clássicos. Nesse sentido, mesmo como um intruso, o imigrante se torna consciente de que estes textos são também seu legado”.

Entre os motivos visuais que perpassam The Nine Muses, talvez nenhum seja tão pungente como a sucessão de registros nos quais o imigrante olha diretamente para a câmera. Distribuídas esparsamente pelo filme, essas imagens de arquivo captam o instante em que o sujeito diaspórico, de súbito, toma consciência de que é filmado. Momento em que aquele tornado objeto da câmera também se permite a fitá-la. No início do filme, os imigrantes são arredios e seus olhares quase sempre furtivos. De cedo, vê-se três meninas se esconderem ao notar a presença do cinegrafista; Elas fogem da câmera e logo correrão até desaparecer do quadro. Mais adiante, um homem num cassino ergue o olhar e encara calmamente a objetiva. Noutro momento, um adulto cutuca a criança ao seu lado para que atente à filmagem. $\mathrm{O}$ menino gira o rosto e olha em direção à lente. Ambos sorriem. Sucedem-se várias outras imagens do tipo; elas povoam o filme, ofertam vislumbres valiosos dessa troca de olhares. Na última, aquela que talvez seja a imagem-síntese de The Nine Muses, o plano é saturado por crianças brancas, negras, asiáticas, mestiças. Sorrindo, elas empurram-se umas contra as outras, disputando a visibilidade no interior do quadro. Entregues à brincadeira, também os filhos de indianos e antilhanos exigem ser vistos, querem participar do jogo instituído pela câmera. Ao captar o encontro entre o olhar do imigrante e o olhar da câmera a serviço do estado, essas imagens sugerem, em chave metonímica, as demandas políticas da geração Windrush. Diante da história, a reciprocidade do olhar remete, por oposição, à não reciprocidade encontrada pelo sujeito diaspórico. Evoca o desengano dos emigrados à Grã-Bretanha. Mas, afinal, que ordem de verdade se pode apreender no intervalo entre olhares que clamam por serem vistos e aquelas outras imagens que insistem em retornar em The Nine Muses, 
as vistas dos espaços hostis, as nevascas, as enchentes, os insultos racistas rabiscados nos muros? Creio que uma passagem do estudo de Laura Marks sobre o cinema diaspórico contemporâneo, no qual a obra de Akomfrah é analisada, ajude a iluminar esses tensionamentos provocados pela montagem. Segundo a autora, esse cinema não estaria tão preocupado "em encontrar a verdade de um acontecimento histórico quanto em fazer a história revelar aquilo que ela não foi capaz de dizer" (MARKS, 2000, p. 29, tradução nossa). No caso de The Nine Muses, o que o filme suscita a partir dos materiais de arquivo, e que a história original contada por eles não estaria apta a exprimir, talvez seja justamente aquilo que jamais veio a ser: as aspirações frustradas e os sonhos irrealizados da geração Windrush. Como atesta o recurso às citações literárias, os filmes apropriados não bastam por si próprios. Em Akomfrah, as imagens existentes parecem convocar imagens que faltam. É como se o arquivo, mais que testemunho, fosse margem necessária para entrever uma história impossível. Ou, ao modo benjaminiano, uma história do que poderia ter sido, conjugada no futuro do pretérito (LISSOVSKY, 2014, p. 33). Assim, aqueles olhares que fitam a câmera nos permitem vislumbrar a frágil utopia dos imigrantes do pós-guerra. Remetem a um anseio por integração que dificilmente viria a ser experimentado em vida.

Akomfrah afirma que The Nine Muses foi concebido como uma libação aos mortos. Percebe seu trabalho com o arquivo como análogo à tradição religiosa dos africanos acostumados a derramar água no solo como chamamento aos espíritos para que venham bebê-la. "É uma forma de evocar os mortos e de indicar que você tem as portas abertas à existência deles, de que eles podem vir sempre que quiserem" (AKOMFRAH, 2015b, p. 36, tradução nossa). Inscreve assim uma demanda espectral na paisagem da Grã-Bretanha. Vale-se da história para reanimar as perguntas suspensas aninhadas nas imagens de arquivo. Essa posição remete ao cerne político das teses benjaminianas sobre a história. Em Benjamin, para que haja justiça, é incontornável atinar para o sofrimento dos mortos. "O dom de despertar no passado as centelhas de esperança é privilégio exclusivo do historiador convencido de que tampouco os mortos estarão em segurança se o inimigo vencer. E esse inimigo não tem cessado de vencer" (BENJAMIN, 2012, p. 244). A memória do sofrimento dos mortos deve perdurar, pois haveria um "encontro secreto" entre o desejo de felicidade irrealizado dos que partiram e o destino da felicidade dos vivos (BENJAMIN, 2012, p. 239). Em The Nine Muses, o ímpeto de acudir aos mortos talvez seja hoje mais premente do que no momento de sua realização. Sete anos após o lançamento do filme, o recuo à origem das migrações massivas às metrópoles europeias ganha outra densidade. O impasse dos refugiados na Europa atualiza tragicamente os dilemas da 
geração Windrush. A ascensão do discurso ultranacionalista e da hostilidade xenófoba que culminaria no Brexit demonstra ainda a persistência da intolerância étnica do pós-guerra. Põe a descoberto a fragilidade da promessa multicultural britânica. Vista desse ângulo, o que nos lega o trabalho de Akomfrah? Se Benjamin está certo em pensar que o passado é incompleto, e se as imagens são dotadas de uma história ulterior, qual destino The Nine Muses atribui aos materiais de arquivo? Akomfrah não se vale das imagens do passado para engendrar, por meio do cinema, uma resolução imaginária dos antagonismos sociais do Reino Unido. Suas operações de montagem não redimem a história. Quiçá, o realizador encontre ao menos um lugar mais hospitaleiro para aquelas imagens em seu filme. Atualiza, assim, a pergunta evocada por cada uma delas. Como no olhar infantil do imigrante que busca a cumplicidade da câmera, momento em que se explicita, no tempo do agora, um anseio por hospitalidade ainda pendente. Em The Nine Muses, a imagem do encapuzado na neve é determinante para entender a trama temporal urdida por Akomfrah. Embora imóvel, aquela figura contra a paisagem monocromática não suscita torpor. Olhos pregados no mar, espaço originário da diáspora africana, ela atualiza uma espera. À sombra do arquivo, reitera a expectativa de outro porvir.

\section{Referências}

AKOMFRAH, J. “Counter-media, migration, poetry”. Film Quarterly, Berkeley, v. 65, n. 2, p. 59-63, 2011. (Entrevista concedida a Nina Power).

. "John Akomfrah: migration and memory". 2012. Disponível em: <https:// goo.gl/yELCOD>. Acesso em: 10 out. 2016.

. "John Akomfrah/Vertigo Sea. 2015a. Disponível em: <https://goo.gl/CxmUTO>. Acesso em: 20 out. 2016.

"Memory and the morphologies of difference". In: SCOTTINI, M.; GA$\overline{\mathrm{LASSO}}$, E. (Orgs.). Politics of memory. Berlin: Archive Books, $2015 \mathrm{~b}$.

BALDWIN, J. “Take me to the water". In: New York: Library of America, 1998. James Baldwin: collected essays.

BANNING, K. “The Nine Muses: Recalibrating migratory aesthetics". Black Camera, Bloomington, v. 6, n. 2, p. 135-146, spring 2015.

BAZIN, A. “Letter from Siberia”. Film Comment, New York, jul. 2003.

BECKETT, S. O inominável. Rio de Janeiro: Nova Fronteira, 1989.

BENJAMIN, W. Magia e técnica, arte e política: ensaios sobre literatura e história da cultura. São Paulo: Brasiliense, 2012. 
Passagens. Belo Horizonte: UFMG, 2006.

BENJAMIN, W.; TARNOWSKI, K. "Eduard Fuchs: collector and historian". New German Critique, Durham, n. 5, p. 27-58, spring 1975.

CADAVA, E. Words of light. Princeton: Princeton University Press, 1997.

DEAKIN, N. et al. Citizenship and British society. London: Panther Books, 1970.

DERRIDA, J. Mal de arquivo. Rio de Janeiro: Relume Dumará, 2001.

DU BOIS, W. E. B. As almas da gente negra. Rio de Janeiro: Lacerda, 1999.

FOUCAULT, M. A arqueologia do saber. Rio de Janeiro: Forense Universitária, 2007.

FRYER, P. Black people in the British Empire. London: Pluto Press, 1988.

GILROY, P. Postcolonial melancholia. New York: Columbia University Press, 2005.

LISSOVSKY, M. Pausas do destino. Rio de Janeiro: Mauad, 2014.

MARKS, L. The skin of the film. Durham: Duke University Press, 2000.

MERCER, K. Welcome to the jungle. London: Routledge, 1994.

NIETZSCHE, F. Assim falava Zaratustra. São Paulo: Saraiva, 2008.

RICHMOND, A. The colour problem. London: Penguin Books, 1961.

SÁNCHEZ-BIOSCA, V. "Exploración, experiencia y emoción de archivo". Aniki, v. 2, n. 2, p. 220-223, 2015.

\section{Referências audiovisuais}

CARTAS da Sibéria. Chris Marker, França, 1957.

HANDSWORTH Songs. John Akomfrah, United Kingdom, 1986.

TESTAMENT. John Akomfrah, United Kingdom, 1988.

THE Nine Muses. John Akomfrah, United Kingdom, 2010.

VERTIGO Sea. John Akomfrah, United Kingdom, 2015.

WHO Needs a Heart? John Akomfrah, United Kingdom, 1991. 